\title{
Hypertrophic osteoarthropathy in a sheep
}

\author{
Hisadora Advincula da Silva Chaves Bom $^{1}$ (B) Givaldo Bom da Silva Filho ${ }^{1}$ (D) \\ Silvio Miguel Castillo Fonseca ${ }^{1}$ (i) Stephanie Carrelo de Lima $^{2}$ (D) Huber Rizzo ${ }^{3}$ (i)

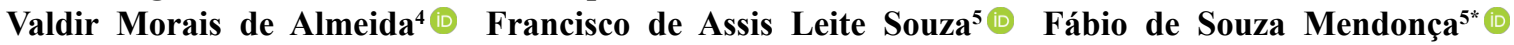

${ }^{1}$ Programa de Pós-graduação em Medicina Veterinária, Universidade Federal Rural de Pernambuco (UFRPE), Recife, PE, Brasil. ${ }^{2}$ Laboratório de Patologia Clínica, Hospital Veterinário, Universidade Federal de Mato Grosso do Sul (UFMS), Campo Grande, MS, Brasil. ${ }^{3}$ Departamento de Medicina Veterinária, Universidade Federal Rural de Pernambuco (UFRPE), Recife, PE, Brasil. ${ }^{4}$ Hospital Veterinário, Universidade Federal de Campina Grande (UFCG), Patos, PB, Brasil.

${ }^{5}$ Laboratório de Diagnóstico Animal, Universidade Federal Rural de Pernambuco (UFRPE), Recife, PE, Brasil. E-mail: fabio.mendonca@ufrpe.br. ${ }^{*}$ Corresponding author.

ABSTRACT: This research described the radiological, clinical and pathological aspects of hypertrophic osteoarthropathy in a seven-year-old Santa Inês ram. The main clinical features were lameness of the thoracic and pelvic limbs, rigid, cracking and enlarged of the humeroradial, humeroulnar and tibiofemoral joints, cervical spine stiffness, and severe lordosis of the thoracolumbar vertebrae. Dyspnea, nasal discharge and abdominal breathing were also observed. On radiographic examination of the thoracic and pelvic limbs, osteoarthrosis with the formation of osteophyte bridging, intra-articular calcification and periosteum reaction were observed. At necropsy were reported bilateral osteophytosis in the humeroradial, humeroulnar, tibiofemoral and interphalangeal joints, and fusion of the bodies of thoracic vertebrae T5-13 T6 and T12-T13. Microscopically, extensive areas of fibrosis were observed in the lungs and the affected joints were thickened by well demarcated and perpendicular orientated woven and trabecular bone proliferation in the epiphysis. The periosteum was also expanded by fibrous connective tissue that extended into and between the new proliferated bone. Based on these findings, hypertrophic osteoarthropathy, which is an unusual condition in sheep, was diagnosed.

Key words: bone disease, pneumonia, lameness, ruminant.

\section{Osteoartropatia hipertrófica em um ovino}

RESUMO: Este trabalho descreve os aspectos radiográficos e clínico-patológicos de um caso de osteoartropatia hipertrófica em um ovino, macho, de sete anos de idade, da raça Santa Inês. Os principais sinais clínicos consistiram em claudicação dos membros torácicos e pélvicos, rigidez, crepitação e aumento das articulações úmero-radio-ulnar e femoro-tibio-patelar, rigidez na coluna cervical e severa lordose das vértebras toracolombares. Dispneia, secreção nasal e respiração abdominal também foram observadas. No exame radiográfico dos membros torácicos e pélvicos, foram observadas osteoartrose com formação de osteófitos em ponte, calcificação intra-articular e reação do periósteo. À necropsia notou-se osteofitose bilateral nas articulações umerorradioulnar, femorotibiopatelar e interfalangiana e fusão dos corpos das vértebras torácicas T5-T6 e T12-T13. Microscopicamente, havia áreas extensivas de fibrose pulmonar e as articulações afetadas encontravamse expandidas pela proliferação de tecido ósseo recém-formado e trabecular, bem demarcado na epífise. O periósteo também estava expandido por tecido conjuntivo fibroso que se estendia dentro e entre o novo osso proliferado. Com base nestes achados, osteoartropatia hipertrófica, que é uma condição inusual em ovinos, foi diagnosticada.

Palavras-chave: doença óssea, pneumonia, claudicação, ruminante.

Hypertrophic osteopathy/osteoarthropathy is an osteoproliferative syndrome characterized by a neoformation of the subperiosteal bone along the diaphysis and metaphysis of the tubular bones, mainly the radius, ulna, femur, tibia, metacarpus and metatarsus (CRAIG et al., 2016; CONSTABLE et al., 2017). This disease causes pain, lameness and movement restriction, rendering the affected farm animal inapt for breeding (MAIR et al., 1996; MADSON et al., 2009; GUYOT et al., 2011).

There are few cases of hypertrophic osteoarthropathy in farm animals (MAIR et al., 1996; 
GUYOT et al., 2011; BROWNE et al., 2016; KWIRANT et al., 2016; CONSTABLE et al., 2017); therefore, this research aimed to describe the radiological, clinical and pathological aspects of a case of hypertrophic pulmonary osteoarthropathy in a sheep.

A seven-year-old Santa Inês ram was referred for veterinary care presenting emaciation, difficulty in rising, lameness of the pelvic and thoracic limbs, cervical spine stiffness, and severe lordosis of thoracolumbar vertebrae. There was bilaterally flexural stiffness, increased volume in the humeroradial, humeroulnar and tibiofemoral joints and the pelvic limbs were bowed (Figure 1). The mucous membranes were congested, and the ram exhibited dyspnea and serous nasal discharge; breathing was predominantly abdominal.

On radiographic examination of the thoracic and pelvic limbs, osteoarthrosis with the formation of osteophyte bridging and intra-articular calcification with reduction of joint interline, subchondral sclerosis and periosteal reaction were observed in the humeroradial, humeroulnar, tibiofemoral and patellofemoral joints (Figure 2A). The bodies of thoracic vertebrae T5-T6 and T12-T13 were merged. Hematological examination revealed normochromic and normocytic anemia (HT 30.90\%) (normal values ranges from $27 \%$ to $45 \%$ ) (BYERS \& KRAMER, 2010), while calcium and phosphorus (7.1mg/dL and $5.2 \mathrm{mg} / \mathrm{dL}$, respectively) (normal values ranges from 6.62 to 13.48 for calcium and 3.72 to 12.11 for phosphorus) (SOUZA et al., 2016) concentrations and biochemical parameters were within normal limits for the species. There was no bacterial growth in the synovial fluid.

After spontaneous death, necropsy was performed and the lungs presented an irregular appearance, were firm and had slightly diffuse red areas interspersed with light areas (Figure 2B). Bone lesions consisted of bilateral and irregular deposits of porous bone in the epiphyses of the right humeroradial, humeroulnar, tibiofemoral and patellofemoral joints and in the distal phalanges and patellas (Figure 2C and 2D). No lesions were observed on articular cartilages.

Samples from the central nervous system (CNS), thoracic and abdominal organs, ribs and phalanges were collected, fixed in $10 \%$ formalin, routinely processed and stained with hematoxylin-eosin (HE). Bone decalcification was performed in $12 \%$ formic acid solution and $20 \%$ sodium citrate solution.

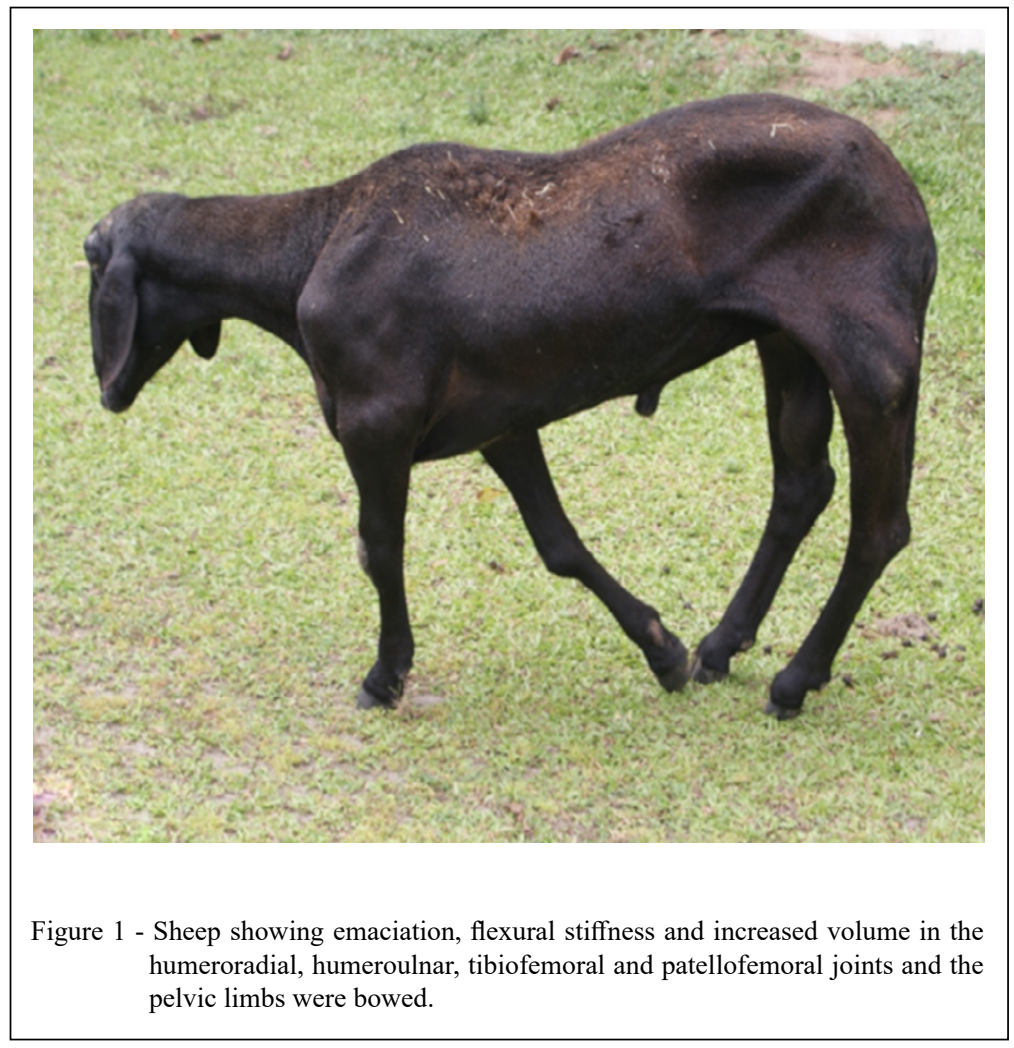

Ciência Rural, v.50, n.12, 2020. 


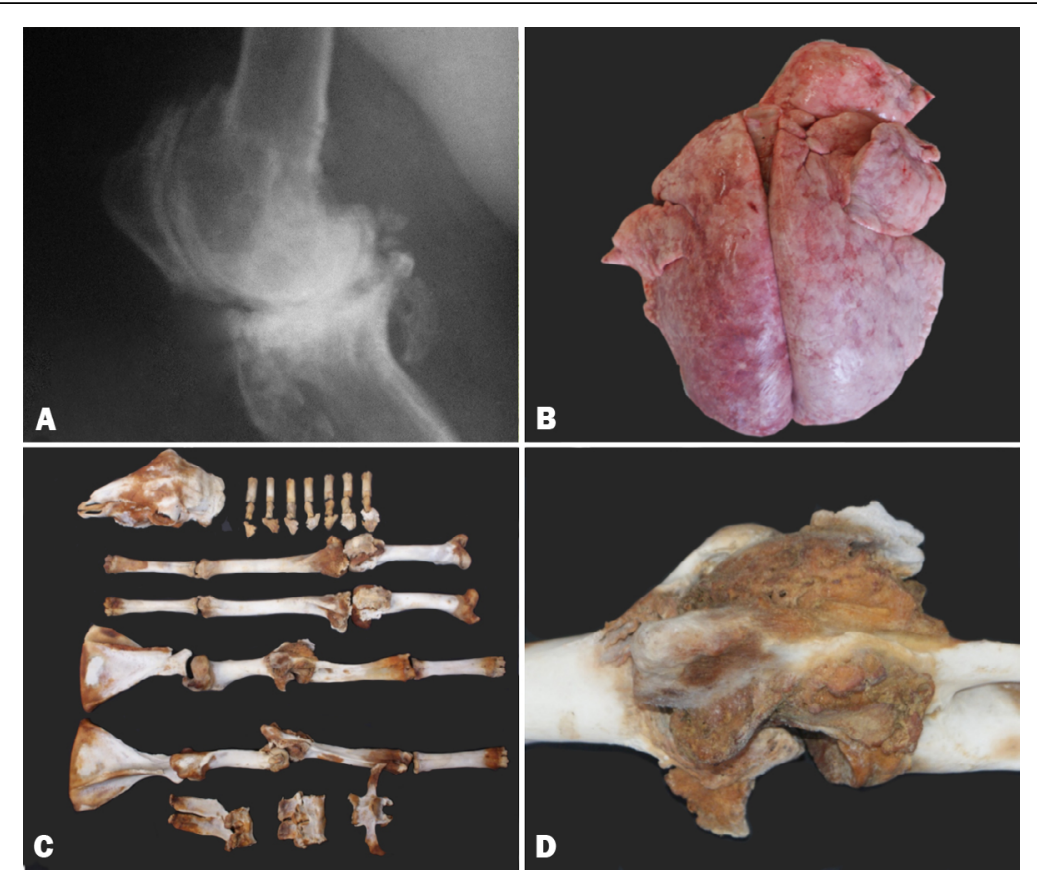

Figure 2 - (A) X-ray image of the tibiofemoral and patellofemoral joints with osteoarthrosis, formation of osteophyte bridging, intra-articular calcification, reduction of joint interline, subchondral sclerosis and periosteal reaction. (B) Dorsal view of the lung presenting an irregular appearance and slightly reddish areas interspersed with light areas. (C and D) Deposition of porous bone in the bone epiphyses conferring a deformed aspect to the joints.

Furthermore, the soft tissue was completely removed from all bones for better visualization of lesions.

On histopathologic examination, there were extensive areas of fibrosis observed in the lungs (Figure 3A). There was also an interstitial mononuclear multifocal inflammatory infiltrate, hyperplasia of type II pneumocytes, atelectasis and emphysema. The periosteum of the affected bones were thickened by fibrous connective tissue and the epiphysis of bones were expanded by woven and trabecular bone that were well demarcated and oriented perpendicular to the cortical bone (Figure 3B). There were no changes in the other thoracic, abdominal and CNS organs.

This article described the clinical, radiological and anatomopathological findings of a case of hypertrophic osteoarthropathy in a ram. Hypertrophic osteoarthropathy is an unusual disease in farm animals (MAIR et al., 1996; GUYOT et al., 2011; BROWNE et al., 2016; KWIRANT et al., 2016), but it is common in humans (YAP et al., 2017). Although, the term osteoarthropathy is not widely used in veterinary medicine (CONSTABLE et al., 2017), we highlighted that in this case, because its use better represents the lesions observed since they clearly affected the joints. There are other reports of animals with a diagnosis of hypertrophic osteoarthropathy; however, this term was used only as a synonym for hypertrophic osteopathy, since the joints were not affected (BUSH et al., 1974; BARRAND \& SCUDAMORE, 2001). According to BARRAND \& SCUDAMORE (2001) radiographs of the limbs of a canine showed evidence of periosteal new bone production on the distal limbs, but without involving the joints, what would be compatible with hypertrophic osteopathy.

In the sheep of this report extensive areas of pulmonary fibrosis were observed, which might have triggered hypertrophic osteoarthropathy. However, the primary cause of this pulmonary alteration has not been determined. It is suggested that fibrosis is a consequence of a pulmonary inflammatory process, according to the clinical signs presented by the sheep. Intrathoracic lesions associated with hypertrophic

Ciência Rural, v.50, n.12, 2020. 


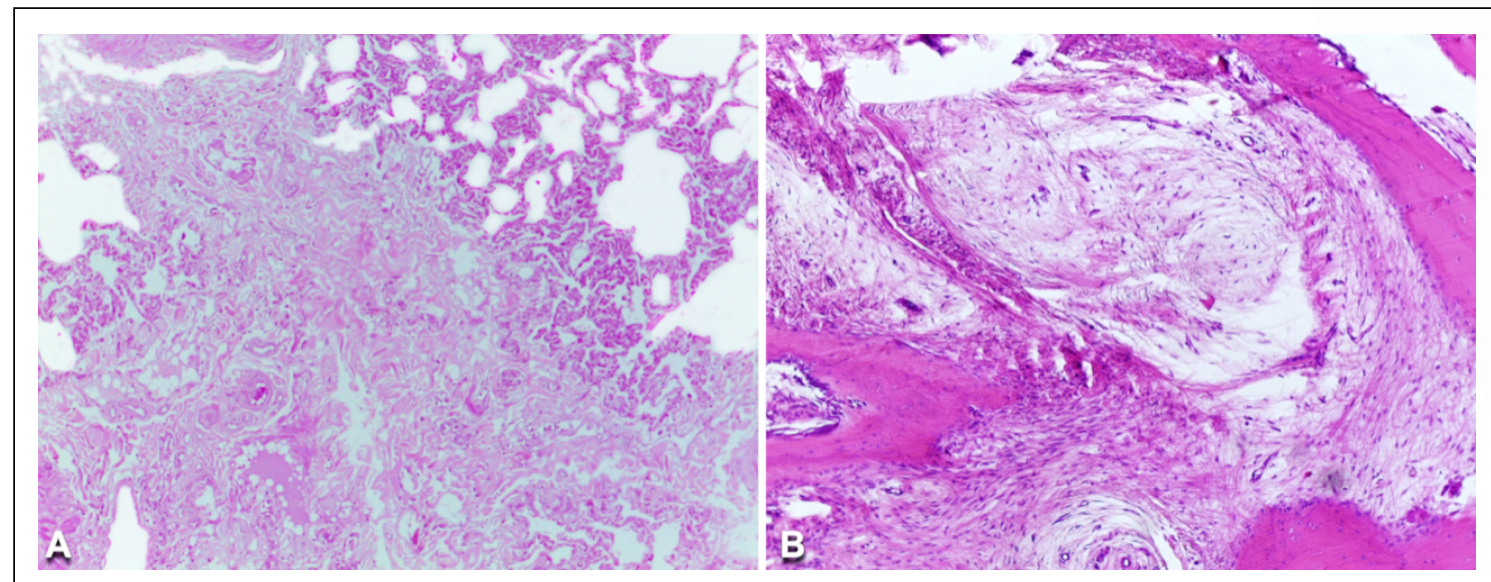

Figure 3 - (A) Histologic lesions in a sheep with hypertrophic osteoarthropathy where diffuse areas of pulmonary fibrosis are noted. HE, 10x. (B) Affected joint was thickened by well demarcated and perpendicular orientated woven bone proliferation. An extended fibrous connective tissue into and between the new proliferated bone is also noted. HE, 40x.

osteoarthropathy included tuberculosis, primary lung tumors, metastatic lung tumors, pulmonary abscessation, mycotic pneumonia, and pulmonary infarction (MAIR et al., 1996; MADSON et al., 2009; GUYOT et al., 2011).

The exact mechanism of the pathogenesis of hypertrophic osteoarthropathy is still unclear. It is also not known how lung injuries can lead to this disease, but it is believed that cytokines and growth factors, including platelet-derived growth factor (PDGF), prostaglandin $\mathrm{E}_{2}\left(\mathrm{PGE}_{2}\right)$ and vascular endothelial growth factor (VEGF) participates in the (CRAIG et al., 2016; YAP et al., 2017). Many of these humoral factors are hypoxia-induced agents, which may account for the presence of clubbing in different hypoxic and malignant illnesses (YAP et al., 2017). Support for this hypothesis was derived from the vascular endothelial growth factor and platelet derived growth factor released from platelets within abnormal limb circulation contribute to the development of the bone lesions (CRAIG et al., 2016). Based on that, we suggested that pulmonary fibrosis has released high levels of growth factors and these have spread in the systemic circulation causing hypertrophic osteoarthropathy in the case of this ram.

In sheep, the differential diagnosis should considerer other diseases like degenerative articular disease, hypervitaminosis $\mathrm{D}$, enzootic calcinosis, and chronic intoxication by fluorine. In these cases, affected animals also present lameness, weight loss, stiffness while walking, and the deposition of porous structures, as observed in hypertrophic osteopathy/ osteoarthropathy (CRAIG et al., 2016; CONSTABLE et al., 2017). On those cases, the articular cartilages could have irregularly worn or could be absent with the subchondral bone exposed (CONSTABLE et al., 2017). Calcification of tendons, ligaments, large vessel walls, compaction, osteopetrosis and erosions in articular cartilage are observed in cases of hypervitaminosis D and enzootic calcinosis (CRAIG et al., 2016). Animals chronically intoxicated by fluorine present widespread and non-uniform periosteal hyperostosis and dental changes when the teeth are in the development phase and enamel formation (CONSTABLE et al., 2017). Degenerative articular disease, hypervitaminosis $\mathrm{D}$, enzootic calcinosis, and chronic intoxication by fluorine were ruled out of the diagnosis due the absence of characteristic lesions.

Based on clinical, radiological and pathological findings, the first case of hypertrophic osteoarthropathy, which is an unusual condition, was diagnosed in a sheep.

\section{ACKNOWLEDGEMENTS}

To Conselho Nacional de Desenvolvimento Científico e Tecnológico - Process 304804/2018-5) and Coordenação de Aperfeiçoamento de Pessoal de Nível Superior (CAPES - Finance Code 001) for the financial support.

\section{DECLARATION OF CONFLICT OF INTERESTS}

The authors declare no conflict of interest. The founding sponsors had no role in the design of the study; in the 
collection, analyses, or interpretation of data; in the writing of the manuscript, and in the decision to publish the results.

\section{AUTHORS' CONTRIBUTIONS}

The authors contributed equally to the manuscript.

\section{REFERENCES}

BARRAND, K. R.; SCUDAMORE, C. L. Canine hypertrophic osteoarthropathy associated with a malignant Sertoli cell tumor. Journal of Small Animal Practice, v.42, n.3, p.143-145, 2001. Available from: $<$ https://doi.org/10.1111/j.1748-5827.2001. tb02011.x>. Accessed: May, 10, 2019. doi: 10.1111/j.17485827.2001.tb02011.x.

BROWNE, N. S. et al. Hypertrophic osteopathy secondary to metastatic ovarian adenocarcinoma in a mare. The Canadian Veterinary Journal, v.57, p.1237-1241, 2016. Available from: $<$ https://www.ncbi.nlm.nih.gov/pmc/articles/PMC5109623/pdf/ cvj_12_1237.pdf $>$. Accessed: Apr. 8, 2020.

BUSH, R. M. et al. Hypertrophic pulmonary osteoarthropathy in a lioness (Panthera Leo). Journal of the American Veterinary Radiology Society, v.15, n.2, p.84-90, 1974. Available from: $<$ https://doi.org/10.1111/j.1740-8261.1974.tb00688.x>. Accessed: May, 10, 2019. doi: 10.1111/j.1740-8261.1974.tb00688.x.

BYERS, S. R.; KRAMER, J. W. Normal hematology of sheep and goats. In:_. WEISS, D.J; WARDROP, K. J. Schalm's veterinary hematology. 5 ed. Iowa: Wiley-Blackwell, 2010. Cap.108, p.836-842.

CONSTABLE, P. D. et al. Diseases of the musculoskeletal system. In: $\quad$ Veterinary Medicine: a textbook of the diseases of cattle, sheep, pigs, goats and horses. Saint Louis: Elsevier, 2017. Chap.15, p.1371-1539.
CRAIG, L. E. et al. Bones and joints. In: Maxie MG. Jubb, Kennedy, and Palmer's Pathology of Domestic Animals. St. Louis: Elsevier, 2016. Chap.1. p.16-163.

GUYOT, H. et al. A case of hypertrophic osteoarthropathy in a Belgian blue cow. The Canadian Veterinary Journal, v.52, n.12, p.1308-1311, 2011. Available from: <https://www.ncbi.nlm.nih gov/pmc/articles/PMC3215463/pdf/cvj_12_1308.pdf >. Accessed: Dec. 12, 2019.

KWIRANT, L. A. A. et al. Hypertrophic osteopathy associated with systemic granulomatous disease in a horse. Semina: Ciências Agrárias, v.37, p.897-902, 2016. Available from: $<$ http://dx.doi. org/10.5433/1679-0359.2016v37n2p897>. Accessed: Mar. 24, 2020. doi: 10.5433/1679-0359.2016v37n2p897.

MADSON, D. M. et al. Systemic Conidiobolus incongruus infection and hypertrophic osteopathy in a white-tailed deer (Odocoileus virginianus). Journal of Veterinary Diagnostic Investigation, v.21, n.1, p.167-170, 2009. Available from: <https://doi.org/10.1177/104063870902100131>. Accessed: Dec. 12, 2019. doi: 10.1177/104063870902100131.

MAIR, T. S. et al. Hypertrophic osteopathy (Marie's disease) in Equidae: a review of twenty-four cases. Equine Veterinary Journal, v.28, n.4, p.256-262, 1996. Available from: <https://doi org/10.1111/j.2042-3306.1996.tb03088.x>. Accessed: Dec. 12, 2019. doi: $10.1111 / \mathrm{j} .2042-3306.1996 . t b 03088 . x$.

SOUZA, B. C. et al. Determination of magnesium, chloride, calcium and phosphorus serum reference values for Dorper and Santa Inês sheep breeds. Pesquisa Veterinária Brasileira, v.36, p.167-173, 2016. Available from: <https://doi.org/10.1590/S0100-736X2016000300004>. Accessed: Apr. 29, 2020. doi: 10.1148/rg.2017160052.

YAP, F. Y. et al. Hypertrophic osteoarthropathy: Clinical and imaging features. Radiographics, v.37, p.157-195, 2017. Available from: < https://doi.org/10.1148/rg.2017160052>. Accessed: Apr. 29, 2020. doi: 10.1148/rg.2017160052. 